УДК 373.2.035:331

DOI: https://doi.org/10.33989/2524-2474.2019.74.196670

ЮЛІЯ ЛУКАШОВА

ORCID: 0000-0001-8540-9531

(Полтава)

Place of study: Poltava V.G. Korolenko National Pedagogical University

Country: Ukraine

Email: julia.lukashova95@gmail.com

\title{
ОЛЕНА ГНІЗДІЛОВА
}

ORCID: 0000-0001-7706-2427

(Полтава)

Place of study: Poltava V.G. Korolenko National Pedagogical University

Country: Ukraine

Email: gnizdilovae@gmail.com

\section{ПРОБЛЕМА ТРУДОВОГО ВИХОВАННЯ ДІТЕЙ ДОШКІЛЬНОГО ВІКУ В ІСТОРИКО-ПЕ- ДАГОГІЧНІЙ РЕТРОСПЕКТИВІ}

У статті схарактеризовано ідеї трудового виховання в різні історичні періоди його розвитку. Доведено, що наукові надбання минулого, $є$ невід'ємною складовою розвитку нової педагогічної думки. Встановлено, що XIX - початок XX століть залишили у світовій культурі низку виховних систем, у яких реалізувався могутній педагогічний потенціал праці. Підкреслено, що в розробці теорії трудового виховання дошкільників у період радянських часів педагоги у своїх дослідженнях зверталися до виховних можливостей дитячої праці, формування моральних якостей під впливом різних видів трудової діяльності, а також методики керівництва дитячою працею. Виявлено, що тривалий період трудова діяльність розглядалася як морально-освітній фактор розвитку підростаючого покоління, а працелюбність як важлива моральна риса особистості. 3'ясовано, що в останні роки в теоретичних дослідженнях простежується спад інтересу до питань трудового виховання дітей. Дослідження вчених спрямовані на вивчення закономірностей побудови педагогічного процесу з метою цілісного впливу на трудовий розвиток дітей, формування уявлень про працю та професії дорослих, розвиток базових якостей в трудовій діяльності дітей, встановлення місця трудового виховання в умовах пошуку нових підходів організації навчально-виховного процесу в ЗДо.

Ключові слова: трудове виховання; діти дошкільного віку; ознайомлення з працею дорослих; наукові дослідження; персоналія.

Постановка проблеми в загальному вигляді. Однією з головних вимог сьогодення є створення умов для формування здатної до самоствердження особистості, яка творчо сприймає світ та має бажання до виконання соціально значущої діяльності. У зв'язку з цим особливого значення набуває праця, як основна і неодмінна умова життєдіяльності людини, вона відіграє визначальну роль у житті суспільства й окремого індивіда, оскільки спрямована на розвиток здібностей, набуття навичок, формування самовдосконалення та орієнтує на дотримання дисципліни та прийняття оперативних рішень. Особистісне зростання людини великою мірою залежить від правильно організованої трудової активності, найдоцільніше їі розпочинати в період дитинства.

Аналіз основних досліджень і публікацій. Питання трудового виховання дітей знайшло своє відображення в історії вітчизняної педагогіки: працях Дж. Дьюі, Г. Кершенштейнера, К. Ушинського та інших. Окремі теоретичні та методичні аспекти питання розкрито в багатьох дослідженнях педагогів. Зокрема, проблемою виховання у дітей працелюбності займалися П. Блонський, А. Макаренко, Є. Тихеєва, С. Шацький; над розробкою трудового виховання дітей у дошкільних установах працювали З. Борисова, Т. Введенська, Р. Жуковська, Д. Менджерицька, Є. Радіна, О. Усова, Т. Цвелих; значення гри в трудовому вихованні дітей вивчали Л. Климакова, І. Лаунер, В. Нечаєва; розвиток моральних якостей у трудовій діяльності досліджували М. Богданова, Р. Буре, В. Логінова, Т. Поніманська; виховання любові та поваги до праці відображено у роботах Г. Бєлєнької, Г. Годінової, Т. Маркової, Я. Неверович, Л. Образцової; організацію спільної трудової діяльності дітей розглядали В. Павленчик, Ю. Приходько, Л. Шашкова. Питання ознайомлення дітей з працею дорослих висвітлено в працях Л. Артемової, Н. Бойченко, С. Галайди, С. Котлярової, Н. Крилової, Т. Макєєвої, М. Машовець; методику ознайомлення дітей дошкільного віку з професіями схарактеризовано А. Булак, В. Глотовою, Л. Пісоцькою, В. Сафоновою, Д. Сергеєвою.

Попри те, що проблема трудового виховання дітей була предметом дослідження багатьох учених, узагальнення нині потребують теоретичні здобутки педагогів минулого і їх інтерпретація у сучасних умовах.

Мета статті - висвітлити генезис проблеми трудового виховання дітей дошкільного віку в педагогічній теорії і практиці.

Виклад основного матеріалу дослідження. Педагогічна практика XIX - початку XX століть залишила у світовій культурі низку виховних систем, у яких реалізувався могутній педагогічний потенціал праці, авторами яких стали зарубіжні та вітчизняні вчені: Дж. Дьюі, Г. Кершенштейнер, К. Ушинський, П. Христианович, С. Шацький. Першочергового значення трудовому вихованню надавав американський педагог Дж. Дьюї, вважаючи його основним засобом підготовки підростаючого покоління до життя. Автор проекту 
німецької трудової школи Г. Кершенштейнер, особливу увагу приділяв питанню трудового виховання особистості, він пов'язав працю з оволодінням основами професії, а також запропонував створити додаткові школи, в яких мало забезпечуватися професійно-технічне навчання і розвиток трудових навичок, виконання громадських обов'язків.

К. Ушинський вказував на велике значення трудової діяльності у вихованні дітей. Їй присвячена наукова робота - «Праця у її психологічному та виховному значенні» (1860р.), в якій обгрунтовано залучення дітей до «вільної праці», як необхідної умови для розвитку почуття людської гідності. Дуже важливими $є$ методичні вимоги К. Ушинського до організації дитячої праці: трудова діяльність повинна бути різноманітною, посильною і неодмінно такою, що активізувала б роботу дитячої думки. В основу педагогічного процесу К. Ушинський поклав працю в усіх її проявах, вважаючи її головним фактором людської досконалості, а працьовитість - одним з основних показників людяності. Ці ідеї продовжували розробляти і втілювати в життя його послідовники - Є. Водовозова, А. Симонович, Є. Конраді та інші.

Зокрема, А. Симонович у свої̆ праці «Дитячий садок» (1907р.), надавала великого значення роботі дітей в саду. Вона наголошувала на думці, що розвиток фізичних сил і м'язів тіла, дихання чистим повітрям, виховання самостійності та набуття чуттєвих вражень, це велика користь для життя дитини в майбутньому. А. Симонович звернула увагу на те, що дитина $є$ найдіяльнішим працівником у всьому світі, адже у своїй творчій діяльності вона не знає меж. $Є$. Водовозова вважала, що наймогутнішим важелем морального успіху дитини $€$ виховання у неї волі. Надавала великого значення розвитку віри у свої сили. Вагомим елементом морального успіху дитини, на їі думку є: фізична праця, посильна домашня буденна робота, а також спостереження за навколишньою природою.

Слід зазначити, що у 1917 - 1919 рр. було створено нову національну педагогічну систему дошкільного виховання. Її основоположники, зокрема О. Дорошенко, Н. Лубенець, С. Русова розглядали працю як моральноосвітній фактор розвитку підростаючого покоління. На думку С. Русової, дитяча праця є головною основою виховання і до неї необхідно залучати дітей з наймолодшого віку. Педагог підкреслювала особливе значення ручної праці, яка повинна забезпечити активність дітей, насолоду від отриманих результатів та створити позитивний настрій у вихованців під час трудової діяльності. Вона наголошувала на необхідності залучення дітей до господарсько-побутової праці. На її переконання, діти повинні виконувати трудові доручення, такі як витирання пилу, поливання квітів, годування та догляд за тваринами. Педагог висувала ряд вимог до організації трудового виховання дітей дошкільного віку та рекомендувала привчати дітей самообслуговування.

Значний уплив на роботу українського дошкілля мали погляди О. Дорошенко. У своїй науковій діяльності педагог зверталася до проблеми трудового виховання дітей і простежила тісний зв'язок праці та гри дитини. О. Дорошенко була однією з перших у теорії дошкільного виховання, хто приділив увагу відмінностям інтересів хлопчиків та дівчаток при виборі ручної праці (Єськова, 2007, с. 11).

У 20 - 30 рр. ХХ ст. працелюбність визначалася педагогами як важлива моральна риса особистості. Науковці та педагоги-практики цього періоду (П. Блонський, П. Волобуєв, Л. Горшелева, А. Макаренко, Є. Тихеєва, С. Шацький та ін.) пропонували активно залучати дітей до трудової діяльності. Зокрема, засновник товариства «Дитяча праця та відпочинок» С. Шацький у своїй діяльності звертався до ідей «вільного виховання». Він вважав, що фізична праця здійснює організуючий вплив на життя дитячого колективу. Трудові заняття мають бути джерелом знань про природу, сільськогосподарське виробництво, а також допомагати формуванню трудових навичок.

У своїй праці «Сучасний дитячий садок, його значення й устаткування» (1920 р.) Є. Тихєєва підкреслювала, що діти повинні виконувати реальну, потрібну, корисну працю, а набуті під час неї знання, мають пов'язуватись 3 практичним застосуванням та розумовою діяльністю. Значне місце педагог відводила ручній праці, головна мета якої розвиток розуму дитини та всіх її духовних здібностей.

Питання трудового виховання підростаючого покоління детально розглядав Я. Чепіга у праці «Азбука трудового виховання» (1922 р.). Автор наголошував на взаємозв'язку гри та праціу житті дитини. Він вважав, що праця має велике соціальне значення для виховання, тому треба її використовувати з ранніх років, обов'язково враховуючи вікові особливості дитини, її нахили та інтереси (Єськова, 2007, с. 9).

Центральною проблемою педагогічної теорії та практики А. Макаренка є організація і виховання дитячого колективу. На думку педагога, трудове виховання $є$ важливим елементом не тільки зміцнення фізичного здоров'я особистості, але й чинником згуртування дитячого колективу. У своїй праці «Книга для батьків» (1937р.) наголошував, що користь праці визначається у психічному, духовному розвитку людини, надавав рекомендації батькам щодо трудового виховання дитини в сім'ї.

Аналіз історико-педагогічних джерел свідчить, що до кінця 30-х рр. ХХ століття склалися провідні теоретичні положення щодо організації трудового виховання дошкільників, були сформульовані основні принципи трудового виховання дітей, а саме: систематичність, послідовність виховання, його зв'язок з життям, урахування вікових психофізіологічних особливостей розвитку дитини, єдність сімейного та дошкільного виховання, провідна роль вихователя у формуванні дитячої особистості (Яковенко, 2018, с. 196). Над розробкою питань трудового виховання дітей у дошкільних установах у цей час працювали Н. Ветлугіна, Р. Жуковська, Д. Менджерицька, Є. Радіна й інші.

Проте, розвиток нових ідей трудового виховання дітей дошкільного віку був загальмований трагічними суспільно-історичними подіями, що відбулися в першій половині 40-х років XX століття.

У післявоєнні роки активність щодо ідей турового виховання дітей дошкільного віку була низькою. Ха- 
рактерним був пошук шляхів його удосконалення. Змінилося ставлення до потреб і можливостей дітей та дошкільного виховання як галузі освіти. Науковці прагнули довести необхідність перегляду завдань трудового виховання дітей дошкільного віку (Т. Введенська, Т. Цвелих, О. Усова).

Радість мирної праці й результативність спільних трудових дій у повоєнні роки відображалась у трудовій діяльності дітей в умовах дитячого садка (Цюпак, 2012, с. 58). Знаний фахівець у галузі дошкільної дидактики О. Усова зазначала, що у суспільному середовищі в дитини розвиваються певні види діяльності, такі як гра, початки праці та учіння, саме вони визначають їі стосунки з оточуючими людьми та формують ї особистість i впливають на процес розумового, морального, фізичного і художнього виховання і розвитку. На думку педагога, у процесі трудової діяльності дитина набуває певних знань, умінь, засвоює ставлення до навколишньої дійсності, звички і навички суспільного життя.

У 60 -х роках XX століття трудове виховання поступово повертається в ряд рівноцінних компонентів дошкільного виховання. Праця розглядалася у взаємозв'язку з іншими видами діяльності як засіб збагачення знань, формування у вихованців позитивних морально-етичних уявлень. Педагоги у своїх дослідженнях надавали великого значення грі в трудовому вихованні дітей (Л. Климакова, В. Нечаєва), вихованню моральних якостей у трудовій діяльності (М. Богданова, Л. Образцова), вихованню любові до праці (Я. Неверович, Л. Образцова). У цей період науковці зверталися до питання ознайомлення дітей з працею дорослих (А. Булак, В. Глотова).

Період 70-х років XX століття відзначився високим інтересом педагогів до проблеми формування у дітей уявлень про працю дорослих (Н. Бойченко, В. Логінова, В. Сафонова, Д. Сергеєва). Ці ідеї знайшли відображення в дисертаційних дослідженнях В. Глотової «Формування уявлень про працю дорослих у дітей старшого дошкільного віку» (1974р.) та С. Котлярової «Ознайомлення в дитячому садку з працею дорослих» (1975 р.).

Вагоме значення для розвитку методики трудового виховання мали праці керівника лабораторії морального і трудового виховання дітей дошкільного віку, наукового співробітника НДІ дошкільного виховання АПН СРСР Р. Буре, яка досліджувала структуру організованої трудової діяльності та методику керівництва нею. У трактатах «Виховання дошкільників у праці. Посібник для виховання в дитячому садку» (1971 р.), «Навчайте дітей працювати» (1983р.) вона грунтовно розкрила зміст, основні завдання, форми організації трудового виховання дітей дошкільного віку, прийоми навчання дітей трудовим навичкам у різних вікових групах, розглянула різновиди трудової діяльності дітей у міській та сільській місцевості, механізми виховання взаємовідносин дітей під час трудової діяльності.

Нова хвиля наукової та публікаційної активності почалася у 80-ті роки XX століття. Основною ідеєю було удосконаленням змісту дитячої праці на психолого-педагогічних засадах. Науковці у цей період зверталися до проблеми моральності в трудовому вихованні дітей (А. Глущенко, С. Козлова, Т. Поніманська). Розвитку набувала ідея щодо організації колективної праці дітей на основі співробітництва з метою формування в них доброзичливих взаэмин, мотивів суспільно корисної праці (Г. Годіна, В. Павленчик, Ю. Приходько). Продовжувалися дослідження проблеми ознайомлення дітей з працею дорослих (С. Галайда, Н. Крилова, Т. Макєєва), ознайомлення дошкільнят з людиною-трудівником, його ставленням до праці: з працею шофера (М. Бурикіна), сільськогосподарською працею (Г. Марочко). Дослідженню цього питання було присвячено декілька дисертаційних досліджень. Зокрема, Н. Крилової «Формування системних знань про працю дорослих у дітей старшого дошкільного віку» (1982р.), Т. Макєєвої «Формування уявлень про працю дорослих у дітей 5-6 років життя в різновікових групах сільського дитячого саду» (1989р.), а також у друкованих працях П. Ігнатенко «Роль трудового виховання у виборі професії» (1988р.), М. Захарової «Професійна орієнтація дошкільників» (1988 р.). Заслуговує окремої уваги робота Л. Артемової «Ознайомлення дітей з працею дорослих» (1988 р.), в якій педагог дала методичні настанови щодо ознайомлення дошкільників з працею дорослих у поєднанні 3 організацією дитячої трудової діяльності.

Значний вплив на розвиток теорії трудового виховання здійснила 3. Борисова. Концептуальна основа її вчення наголошує на необхідності поціновування трудової діяльності дітей, що закладає підгрунтя для формування відповідальності, наполегливості, цілеспрямованості, працелюбності. У посібниках «Виховання дошкільників в праці» (1997р., 2002 р.), колектив авторів (Г. Бєлєнька, М. Машовець, Н. Кот, Н. Кривошея) під керівництвом 3. Борисової розкрили значення, завдання і зміст трудового виховання дітей дошкільного віку, схарактеризували основні види дитячої праці, шляхи ознайомлення дітей з працею дорослих.

Важливими для розвитку трудового виховання дітей у цей період є ідеї Т. Поніманської, яка окреслила етапи розвитку теорії трудового виховання в дошкільній освіті та актуальні проблеми в нових соціальноекономічних умовах. У своїй науковій діяльності Т. Поніманська звернула увагу на те, що трудове виховання будучи спрямованим на особистісний розвиток, тісно пов'язане з фізичним, моральним, розумовим вихованням. Педагог наголошувала на збереженні найтіснішого зв'язку дитячої праці з грою та необхідності використання ігрових прийомів під час її організації, а також ставлення до праці як до обов'язку. У підручнику «Дошкільна педагогіка» Т. Поніманська представила значний масив теоретико-методичних настанов з організації трудового виховання у закладах дошкільної освіти.

Аналізуючи дослідження сучасних українських науковців у галузі дошкільної освіти, робимо висновок про спад інтересу до цієї проблеми. Дисертаційні праці з питання трудового виховання дошкільників зосередженні навколо дослідження ідей трудового виховання в різні історичні періоди його розвитку. Зокрема наукові роботи: С. Лозинської «Формування елементарних трудових навичоку дітей дошкільного віку 
в Україні (1918-1939 рр.)» (2014р.), Є. Антипіна «Ідеї наступності трудового виховання дітей дошкільного та молодшого шкільного віку у вітчизняній педагогічній думці (кінець XIX-го - 30 - ті роки XX століття)» (2017р.); О. Літіченко «Ідеї трудового виховання дітей дошкільного віку в педагогічній пресі (50-ті - 80-ті pp. ХХ століття)» (2018р.).

Над розробкою методики трудового виховання дітей активно працюють Г. Бєлєнька, Н. Гавриш, М. Машовець. Зокрема, Г. Бєлєнька приділяє увагу дослідженню виховання елементів культури праці у дітей старшого дошкільного віку, а також надає вагомого значення ознайомленню дітей з професіями. Вона підкреслює, що знання про працю дорослих відіграють вирішальну роль у формуванні поваги до праці. Погоджуємося з ії думкою, що «знання про суспільну значущість праці, їі мотиви та спрямування регулюють вчинки дітей, перебудовують їх ставлення до власної трудової діяльності та продуктів людської праці, сприяють формуванню моральних якостей» (Бєлєнька, 2010, с. 84).

Питання формування лідерських якостей у трудовій діяльності дітей дошкільного віку знайшло відображення в публікаціях Г. Бєлєнької, Н. Гавриш, О. Ліннік. У працях М. Машовець наголошує на ефективності залучення дітей до трудової діяльності з наймолодшого віку, звертає увагу на педагогічні умови наступності у трудовому вихованні дітей старшого дошкільного та молодшого шкільного віку.

У дослідженнях Н. Грама, Г. Григоренко, Р. Жадан, Н. Кривошиї, Т. Михайліченко, С. Смелянської праця людини розглядається як чинник формування економічного добробуту нації. Педагоги діляться досвідом формування економічної грамотності та здатності сприймати і використовувати економічну інформацію в життєвих ситуаціях.

Публікації Г. Бєлєнької, М. Машовець, Л. Пісоцької засвідчують низький рівень знань у дітей дошкільного віку про сучасні професії та, як наслідок, відсутність творчих ігор із відповідними сюжетами. Сучасні науковці переконливо доводять, що діяльність та активність є природною необхідністю дитини. Праця становить базову цінність життя людини. Розвиток ії базових якостей включає працелюбність, як вияв діяльнісного ставлення до навколишнього світу (Машовець, 2018, с. 148).

Висновки дослідження і перспективи подальших розвідок. Генезис ідеї трудового виховання дітей дошкільного віку має хвилеподібний характер. У XIX ст. - 40 pp. XX ст. вона розвивалася від глибокого розуміння сутності й необхідності праці у житті людини, активного залучення дітей дошкільного віку до посильної трудової діяльності до повного нехтування цією проблемою у воєнні і повоєнні роки. Інтерес до питання відновився у 60-х роках.Учені цього періоду розглядали трудове виховання у взаємозв'язку з іншими видами діяльності, а також як засіб формування у дітей позитивних морально - етичних уявлень. Значного розквіту трудове виховання набуло у 80 -ті роки, основною ідеєю якого було удосконаленням змісту дитячої праці та організація колективної трудової діяльності дітей.

У науковій педагогічній думці XX ст. значного поширення набула проблема ознайомлення дітей з працею дорослих. У своїх дослідженнях до неї зверталися Л. Артемова, Н. Бойченко, А. Булак, С. Галайда, В. Глотова, В. Логінова, Д. Сергеєва, Т. Макєєва та інші. Нажаль, у сучасній освіті простежується спад інтересу до цього питання, саме тому потребує збагачення зміст, вдосконалення методів і засобів трудового виховання дітей дошкільного віку як вагомого чинника самоствердження дитини в майбутньому.

\section{СПИСОК ВИКОРИСТАНОЇ ЛІТЕРАТУРИ}

Бєлєнька Г. В. Зростання дошкільника в праці. Київ : Шк. світ, 2010. 112 с.

Гуцан Л. А. Проблема трудового виховання особистості в історичному вимірі. Педагогіка та історія педагогіки. 2019. Т. 1, вип. 10. С. 167-172.

Єськова Т. Л. Проблема виховання в дошкільників працелюбності у вітчизняній педагогічній теорії та практиці у першій третині XX ст. Збірник наукових праць Бердянського державного педагогічного університету. Педагогічні науки. Бердянськ : БДПУ, 2007. № 3. С. 8-13.

Машовець М. А. Трудове виховання дітей дошкільного віку: пошук нових ідей. Інноватика у вихованні. 2018. Вип. 7(2). С. $147-153$. Русова С. Ф. Вибрані педагогічні твори : у 2 кн. Київ : Либідь, 1997. Т. 1. 271 с.

Ушинський К. Д. Вибрані педагогічні твори : в 2-х т. Київ : Рад. школа, 1983. Т. 1. 488 с.

Цюпак I. М. Ознайомлення дошкільників з працею дорослих у педагогічних дослідженнях XX ст. Психологія і педагогіка у системі педагогічного знання : матер. міжнар. наук.-практ. конф. Одеса : ПНПУ, 2012. С. 56-60.

Яковенко В. В. Становлення ідей трудового виховання дітей дошкільного віку. Теорія та методика навчання та виховання. 2018. № 44. С. 187-198. doi.org/10.5281/zenodo.1411543.

\section{REFERENCES}

Bielienka, H. V. (2010). Zrostannia doshkilnyka v pratsi [The growth of preschoolers in labor]. Kyiv: Shkilnyi svit [in Ukrainian].

Hutsan, L. A. (2019). Problema trudovoho vykhovannia osobystosti v istorychnomu vymiri [The problem of labor education of the individual in the historical dimension]. Pedahohika ta istoriia pedahohiky [Pedagogy and history of pedagogy], 10. 167-172. Retrieved from https://goo-gl.su/bymTZQf [in Ukrainian].

Mashovets, M. A. (2018). Trudove vykhovannia ditei doshkilnoho viku: poshuk novykh idei [Labor education of preschool children: search for new ideas]. Innovatyka u vykhovanni [Innovation in education], 7 (2). 147-153. Retrieved from http://nbuv.gov.ua/UJRN/inuv_2018_7\%282\%29_18 [in Ukrainian].

Rusova, S. F. (1997). Vybrani pedahohichni tvory [Selected pedagogical works]. (Vol. 1). Kyiv: Lybid [in Ukrainian].

Tsiupak, I. M. (2012). Oznaiomlennia doshkilnykiv z pratseiu doroslykh u pedahohichnykh doslidzhenniakh XXst [Familiarization of preschool children with the labor of adults in pedagogical research of the XX century]. Retrieved from http://ekhsuir.kspu.edu/bitstream/123456789/3211/1 /14_\%D0\%A6\%D1\%8E\% D0\%BF\%D0\%B0\%D0\%BA\%20\%D0\%86.\%D0\%9C.pdf [in Ukrainian].

Ushynskyi, K. D. (1983). Vybrani pedahohichni tvory [Selected pedagogical works] (Vol. 1). Kyiv: Rad. Shkola [in Ukrainian]. 
Yakovenko, V. V. (2018). Stanovlennia idei trudovoho vykhovannia ditei doshkilnoho viku [Becoming of ideas of labour education of children of preschool age]. Teoriia ta metodyka navchannia ta vykhovannia [Theory and methodology of teaching and education], 44. 187-198 [in Ukrainian].

Yeskova, T. L. (2007). Problema vykhovannia v doshkilnykiv pratseliubnosti u vitchyznianii pedahohichnii teorii ta praktytsi u pershii tretyni XX st [The problem of upbringing of hardworking preschoolers in the national pedagogical theory and practice in the first third of the XX century]. Scientific notes of the Berdyansk State Pedagogical University. Pedagogical science, 3. 8-13 [in Ukrainian].

\title{
YULIA LUKASHOVA
}

Place of study: Poltava V.G. Korolenko National Pedagogical University

Country: Ukraine

Email: julia.lukashova95@gmail.com

OLENA HNIZDILOVA

Place of study: Poltava V.G. Korolenko National Pedagogical University

Country: Ukraine

Email: gnizdilovae@gmail.com

ISSUES OF PRESCHOOL CHILDREN LABOR EDUCATION IN HISTORICAL AND PEDAGOGICAL RETROSPECTIVE

The article describes the ideas of labor education during different historical periods of its development. It has been stated that the scientific heritage of the 19th - the beginning of the 20th century left some educational systems in the world culture, in which the powerful pedagogical potential of labor was realized. It has been revealed that labor was regarded as a moral and educational factor of the youngsters' development, and diligence was considered as an important moral quality of a person. In their studies, scientists paid attention to the development of collectivity in the process of children's co-operation and the importance of organizing easy work.

It has been found out that leading theoretical ideas of organization of preschool children labor education had been formulated by the end of the 1930s; its basic principles were formulated, namely: systematicity, sequence of education, connection with life, age-related psychophysiological features of children development, the unity of family and public pre-school education, the leading role of a kindergartener in the process of child personality formation.

It has been revealed that there were two main directions of the development of the theory of preschool children labor education in the Soviet period: 1 . Theoretical foundations of the study (educational opportunities of child labor, its importance, the influence of different types of work on the formation of children's moral qualities); 2. Methodical principles of the guidance of child labor (the most appropriate system of influence by adults on the organization of child labor).

It has been stated that Z.N. Borysova's ideas significantly influenced the development of the modern system of preschool children labor education. She revealed the meaning, tasks, and content of preschool child labor education, characterized the main types of child labor, ways of familiarizing children with adult labor, and had a significant impact on the development of the modern system of labor education preschool children.

It has been emphasized that researchers have recently shown a decline in interest in the issues of child labor education. The scientists' works are oriented on studying regularities of pedagogical process construction with the purpose of holistic influence on labor development of children, formation of ideas about labor and profession of adults, development of basic children's qualities in the process of labor activity, establishment of place of labor education in the conditions of search of new approaches of educational process organization.

It has been proven that the scientific heritage of the past is an integral part of the development of new pedagogical thought. After all, a retrospective analysis of the problem will allow us to take into account the best experience and to use it in the process development and updating of the content of preschool children labor education in modern conditions.

Keywords: labor education; preschool children; familiarization with labor of adult; scientific research; personnel.

одержано 04.09.2019

УДК $378(477.74)$

DOI: https://doi.org/10.33989/2524-2474.2019.74.196671

\author{
НАДІЯ ГРАМАТИК \\ ORCID: 0000-0002-0374-6954 \\ (Ізмаїл) \\ Place of work: Izmail State Humanitarian University \\ Country: Ukraine \\ Email: Gramatiknadea@gmail.com
}

\section{ТРАНСГРАНИЧНИЙ ОСВІТНІЙ ПРОСТІР УКРАЇНСЬКОГО ПОДУНАВ'Я: АКТУАЛІЗАЦІЯ КОМПЕТЕНТНІСНОЇ ПАРАДИГМИ}

Європейський вектор розвитку вищої освіти зумовлює необхідність відтворення кращих національних освітніх традицій, а також оновлення системи підготовки майбутніх фахівців у галузі освіти відповідно до європейських освітніх стандартів. Суттєвою відмінністю змін, у трансформаціях сучасності, є посилення вимог до професійної підготовки майбутніх учителів природничих наук з огляду на багатоаспектну специфіку їх фахової діяльності.

Одним зі шляхів оновлення змісту освіти й узгодження його з сучасними потребами виступає компетентнісна освіта як стратегічно значущий фактор посилення конкурентоздатності майбутніх учителів. Поряд із цим, сьогодні актуальності набуває уточнення спектру компетентностей, що пов'язане з багатьма чинниками, оскільки вони $є$ індикаторами 